\title{
Methodology of Islamic psychotherapy in Islamic boarding school Suryalaya Tasik Malaya
}

\author{
Khairunnas Rajab
}

State Islamic University Suska Riau and Executive Director of Madine el-Jadid Email: khairunnasrajab@gmail.com

\begin{abstract}
Islamic Psychotherapy is a methodology that is based on the Quran and Sunnah. The Quran and Sunnah are sources of knowledge. Islamic psychotherapy provides solutions to mental disorder. Suryalaya Boarding school has provided guidance to patients who are addicted to drugs in order to be recovered. The Islamic psychotherapy model applied at the boarding school is the Sufism-based approach. Sufism is a way to get closer to God. Through the approach, drug-addicted patients can be cured. If the patients realize that God answers their prayers through worship, the sense of sinfulness and guiltiness will gradually disappear. The boarding school has been implementing Islamic psychotherapy of Qadiriyyah-Naqsyabandiyyah approach. Through the approach, the patients succeeded to be completely recovered. This article attempts to explain the important roles of the school in treating patients suffering from mental disorder due to misuse of drugs.

Psikoterapi Islam adalah sebuah metodologi yang berdasarkan al-Qur'an dan al-Sunnah. Al-Qur'an dan al-Sunnah adalah sumber ilmu pengetahuan. Psikoterapi Islam memberikan solusi bagi orang-orang yang mengalami gangguan mental. Pondok Pesantren Suryalaya telah melakukan pembinaan
\end{abstract}


terhadap pasien yang kecanduan narkotika. Model psikoterapi Islam yang diterapkan di pondok pesantren ini adalah psikoterapi dengan pendekatan tasawuf. Melalui pendekatan Tasawuf pasien narkotika dapat dipulihkan. Tasawuf adalah upaya seseorang untuk mendekatkan diri kepada Tuhannya. Apabila pasien narkotika menyadari bahwa Allah mengabulkan doa-doa melalui ibadah, maka perasaan berdosa dan bersalah secara bertahap akan hilang. Pondok Pesantren Suryalaya selama ini telah menerapkan sebuah model psikoterapi Islam dengan pendekatan thariqat Qadiriyyah-Naqsyabandiyyah. Dengan Thariqat Qadiriyyah-Naqsyabandiyah pasien-pasien narkotika dapat disembuhkan secara sempurna. Artikel ini berupaya menjelaskan peran penting Pondok Pesantren Suryalaya dalam penyembuhan pasien yang mengalami gangguan mental akibat penyalahgunaan narkotika.

Keywords: Islamic psychotherapy; Qadiriyah-Naqsyabandiyah; Patients; Therapists; Mental disorder

\section{Introduction}

The Quran gives guidance, teaching and treatment through iman or faith to prevent bad attitudes, such as arrogance, jealousy, hypocrisy, and many others. It educates people to take a right path and guides human beings to act and behave well. It is also methodology of Islamic psychotherapy to heal bad mental attitude. The Quran provides some approaches to treat immoral behavior of an individual. The first approach is the preventive method. ${ }^{1}$ This approach is oriented to the self-integration by controlling, reducing, and avoiding the bad attitude of an individual. The second approach is the therapeutic method. ${ }^{2}$ The Therapeutic method is an individual effort to cure immoral problems. During the treatment, each individual should not engage in immoral acts. This approach emphasizes in disciplinary effort based on the faith and the piety. The third approach is

\footnotetext{
${ }^{1}$ Yahya Jaya, Spiritualisasi Islam dalam Menumbuhkembangkan Kepribadian dan Kesehatan Mental, Jakarta: Ruhama 1992, 83.

${ }^{2}$ Yahya Jaya, Spiritualisasi Islam dalam Menumbuhkembangkan..., p. 83
} 
the method of rehabilitation and reconstruction. ${ }^{3}$

This approach is an intensive treatment by increasing good deeds and avoiding wicked acts. The method of reconstruction and rehabilitation is a manifestation of asking the god for forgiveness by improving the quality of faith and piety. If those three approaches could be realized, the individual psychology will be better. ${ }^{4}$ Those three methods play an important role during the process of psychotherapy. It can be seen from prohibition of drinking alcohol. The Quran forbids a Muslim to kneel in prayer while he is drunk. This prohibition is a preventive action of the Quran in order that a Muslim does not do immoral act.

The Quran protects a Muslim from disadvantages. Drinking alcohol, for instance, is disadvantageous. The prohibition of the Quran, then, is an example of the methodology of the Quran by using medicinal approach. The Quran says,:

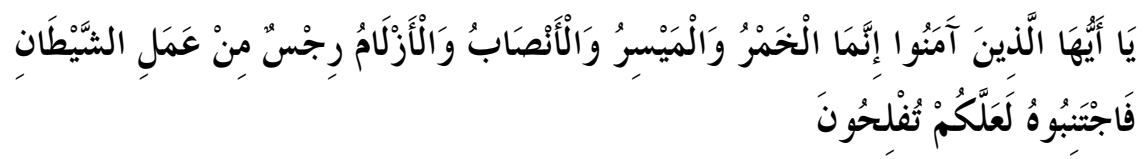

O ye ho believe! Intoxicants and gambling, (dedication of) stones, and (divination by) arrows, are an abomination of Satan's handwork: eschew such (abomination), that ye may prosper. ${ }^{5}$

The above verse explains about the explicitness of Allah's statement related to alcohol. In Islamic psychotherapy, this effort is called as method

${ }^{3}$ Yahya Jaya, Spiritualisasi Islam dalam Menumbuhkembangkan..., p. 83

${ }^{4}$ Those approaches can be seen from following verse, "They ask thee concerning wine and gambling. Say: "In them is great sin, and some profit, for means; but the sin is greater than the profit." They ask thee how much they are to spend; Say: "What is beyond your needs. "Thus doth Allah make clear to you His Signs: In order that ye may consider- (Al-Baqarah 2: 219). Then, in other verse, Allah says" O ye who believe! Intoxicants and gambling, (dedication of) stones, and (divination by) arrows, are an abomination, - of Satan's handwork: eschew such (abomination), that ye may prosper" (Al-Maidah 5: 90).

${ }^{5}$ QS. Al-Mä'idah 5: 90. 
of reconstruction and rehabilitation. In Islamic mystic (Sufi order), there are some methodological approaches in treating the mental health of its followers. The followers of Islamic mystic use the following approaches; firstly, takhalliyya al-nafs ${ }^{6}$ is an effort to protect the followers of Islamic mystic from immoral acts. Psychologically, takhalliyya al-nafs gives a positive influence to the followers of Islamic mystic since it improves their mental health. Those who are free from bad attitude can enter the new stage of their life. In the process of takhalliyya al-nafs, the consciousness of those who follow that process is required. They should be conscious that immoral acts will damage their psychological health. An individual's sin will become obstacle for his psychotherapy. Therefore, in Islamic psychotherapy, those who commit a sin should ask the God for forgiveness and increase their good deeds. An Islamic mystic who follows takhalliyya alnafs will improve his mental health.

Secondly, tahalliyya al-nafs ${ }^{7}$ is the act of the followers of Islamic mystics in improving their faith, piety, good deed, and ethic. In this process, they are controlled by their faith in order to follow the right path. The teaching of Islamic mystic related to tahalliyya al-nafs has a function as medicinal approach. If the process of tahalliyya al-nafs is followed well, it will cure the mental disorder of an individual. Thirdly, tajalliyya al-nafs is psychological gift which presents in the heart of every Islamic mystic contaminated with the patience, resignation, and repentance. There are some rituals or attitudes making Islamic mystic getting tajalliyya al-nafs, namely reciting the Quran, doing a prayer, behaving low profile, being thankful, and act of devotion. The gift of tajalliyya al-nafs is a present from Allah to a Muslim who always approaches to Him sincerely. The approach of tajalliyya al-nafs is a spiritual gift to an Islamic mystic having the strong

\footnotetext{
${ }^{6}$ Proyek Pembinaan PTA, Pengantar Ilmu Tasawuf, Medan: IAIN Sumut, 1981, 99.

${ }^{7}$ Proyek Pembinaan PTA, Pengantar Ilmu Tasawuf..., 123.
} 
faith and good deed. With the faith, piety, good deed, and intensive prayer, an Islamic mystic will reach a deep unconsciousness, namely Allah. It is called by Carl Jung as Archaic. During his unconsciousness, he can transform himself psychologically into spiritual mature. ${ }^{8}$

In general, takhalliyy a al-nafs, tahalliyya al-nafs and tajalliyya al-nafs function as preventive, medicinal, and constructive methods to solve psychological problem and to cure the mental disorder of an individual.

\section{Paralyzing Islamic psychotherapy with the mental health}

Human being is created by Allah in order to realize his task as the caliph of the earth and servant of God avoiding polytheism. He should perform a religious service sincerely. ${ }^{9}$ The content in the faith, religious service, piety, and good deed has a high spiritual value both psychologically and physically. Therefore, a Muslim who has faith, piety and behaves well can improve his mental stability and give good energy for his life. In Islamic psychotherapy, the energy can make an individual reach victory (al-falah), the success (al-najāt), the peace (al-salam), the luck (alfawz), the happiness (al-sa'adah), and the calm (mutma'innah). The energy resulted from the faith, religious service, good deed, and Islamic Sufism cures any mental disorder and improves Islamic personality. The mental health and Islamic personality are manifestation of consciousness, harmony and conformity. A faith is personal relation of an individual to his God. A religious service is oriented with reinforcement of an individual's relation to his God and it will give an implication for his relation to human beings. The piety, good deed, and Islamic Sufism are other forms

${ }^{8}$ Ensiklopedi al-Qur'an, Al-Nafs, dalam Jurnal Ilmu dan Kebudayaan, Ulumul Qur'an, No. 8, Vol.II (1991), 103.

${ }^{9}$ A statement can be seen as a good deed, if it can fulfill three following requirements; a) Sidq al-'azimah, or one has strong and undoubtful willing; b) Sincere; c) based on Islamic teaching. See, Muhammad Sayyid al-Qahtani et.al., Memurnikan Lailahaillallah, transl. Abu Fahmi, Jakarta: Gema Insani Press, 1993, 89. 
of the faith and the ritual which are basically related to habl min Allāh, habl min al-nās, and habl min al-áalam. In a theory of the mental health, a Muslim who performs habl min Allāh, habl min al-nās, and habl min al'alam is a Muslim adapting himself to create Islamic personality and the perfectness of the mental health.

In Islamic Sufism, the approaches of takhalliyya al-nafs, tahalliyya al-nafs and tajalliyya al-nafs are preventive, medicinal, constructive methods and method of rehabilitation. They are method of Islamic psychotherapy in curing the mental disorder. Islamic teachings, such as faith, ritual, piety, good deed, and Islamic Sufism, are methodology of Islamic psychotherapy to improve the mental health. Some aspects found in faith, ritual, and Islamic Sufism, are base on the Islamic concepts which are suitable for curing the mental disorder. If those concepts are implemented, immoral acts can be avoided. ${ }^{10}$ As a result, the implementation of those concepts will create optimism, strength, self confidence, honesty, and fairness. ${ }^{11}$

The change of an individual's attitude from immoral acts to the piety, from paganism to faithful, from cruelty to fairness is a good manifestation in a spiritual journey to the God. ${ }^{12}$ An effort to get Allah's blessing ${ }^{13}$ by improving piety and good deed creates Islamic personality, improves the mental health, ${ }^{14}$ and makes an individual care about the problems of

${ }^{10}$ Unfortunately, many people who have a lot of talents have to live in a suffering; their soul are worry due to many different factors. See, Sayyid Mujtaba Musavi Lari, Psikologi Islam, Bandung: Mizan, 1993, 11.

${ }^{11}$ In order to practice the good behavior, one needs mind, religion, normativity, and morality. Khalil al-Musawi, Kaifa Tabni Shahsiyatak, transl. Ahmad Subandi, Jakarta: Lentera Basritama, 1998, xii.

${ }^{12}$ Budi Munawwar Rahman, Kontekstualisasi Doktrin Islam dalam Sejarah, Jakarta: Paramadina, 1995, 121.

${ }^{13}$ Nurcholish Madjid, Pintu-pintu Menuju Tuhan, Jakarta, Paramadina, 1995, 187.

${ }^{14}$ To be strong and good personality, one has to evaluate and make an evaluation. The acts based on those evaluations without other's intervention. See Frans Magnis Suseno, Etika Dasar (Masalah-masalah Pokok Filsafat Moral), Yogyakarta: Kanisius, 1987, 146-147. 
Islamic society. ${ }^{15}$

Human beings, basically, are given a good and bad potency. The natural tendency of human being is pure. However, in their life, human beings are influenced by many elements that make them bad or good. The psychological development of individuals is strongly influenced by their environment and heredity.

In Islamic psychotherapy, the reinforcement of spiritual values, such as faith, ritual, piety, good deed, and Islamic Sufism, are the basic aspects. The psychological consciousness will reduce confusion, worry, stress, depression, and other mental. These individual behaviors create a consciousness to get a good mental health. In Freud's point of view, Islam views unconsciousness as an important element in curing the mental disorder. ${ }^{16}$

The mental health is a characteristic indicating that an individual is free from mental disorder. The mental health is human's expectation in this world. Each conscious individual will try to fulfill his need. If he can fulfill his need, his mental health will be better. Good mental health is the basic need of human beings. It is the most urgent. Some experts of mental health made a theory of mental health based on different methodology related to the mental disorder. The methodology of the mental health developed systematically by Islam brings the mental of Islamic society healthy.

Victor E. Frankl, by using the methodology of the meaningful life, explains that there is a relationship between psychotherapy and religion. He said that the synthesis of psychotherapy and religion will create, firstly,

\footnotetext{
${ }^{15}$ The psychological freedom means an individual ability in developing and guiding the human's life based on free consciousness and optimum consideration. See, K. Bertens, Etika, Jakarta: Gramedia Pustaka Utama, 1997, 108-109.

${ }^{16}$ The use of unconsciousness term is more suitable than sub-consciousness. In fact, the term of therapy is imbalance, if it is connected with psychoanalysis in which uses the term of to treat or treatment. However, the term of 'therapy' is still used since it is not interpreted literally. Sigmund Freud, Veber Psycho: Feung Vor Tesungea, transl. K. Bertens, Jakarta: Gramedia, 1991, xii.
} 
the theoretical construction or human's concept in all knowledge, such as economy, sociology, medicine, philosophy, psychology, and psychotherapy. Secondly, diagnostic function - psychotherapy analysis can be developed by using religious perception through ijtihad (religious innovation). The third is interactive communication between religious experts and therapists in treating the mental disorder; as an individual, group, and society. ${ }^{17}$ Combination of religion and psychology will create theoretical concept in identifying some problems of mental disorder.

Islam consisting of great spiritual values is able to solve human's psychological problem. Dimensions in Islam such as faith, devotion, charity, morals, and philosophy have systemic methods to gain good mental health. If aspects containing in Islam are able to build good mental health, Islam becomes the first step that can create system and methods of Islamic mental health. Because mental health methods used are based on the Islamic laws, the methods, then, are called Islamic mental health.

Islamic mental health is the Islamization of knowledge. The method used to analyze problems can be done by brightening, applying and implementing values containing in the Quran and Sunnah. Values both in the Quran and Sunnah are the references to analyze data, especially those that deal with faith, devotion, charity, morals, and philosophy. The quality of faith, devotion, charity, morals, and philosophy tested will complete essential perfection of the existence of Islamic mental health. The mental health by strengthening the faith, improving the quality of devotion, managing charity, having great moral and approaching to Allah through a philosophy is a method that results in harmony and good mental health. The conceptualization of Islamic mental health is a new offering for people who are more and more complex and out of control.

${ }^{17}$ Dadang Hawari, Al-Qur'an: Ilmu Kedokteran Jiwa dan Kesehatan Jiwa, Yogyakarta: Dana Bhakti Primayasa, 1997, 21. 
Islam belongs to Allah; a religion messaged to the Prophet Muhammad pbuh, is realistic and able to help human beings to gain happiness and peace. ${ }^{18}$ Islam motivates the followers to obey Allah, to create good relationship among humans (hablun min al-nass), not to bother and not to oppress animals and plants. ${ }^{19}$ Islam containing various dimensions, laws and systems for humans is prepared to solve human's problem so that it can build a strong muttaqin community. ${ }^{20}$

Many modern ways of thinking offered need to observe and think about. Human's problems become more and more complex and difficult to solve, especially those that deal with social and psychological problems that could have been solved so far. Human beings, of course, need effective and efficient ways out soon. Islam teaches faith, devotion, charity, moral and ritual events through tasawuf; as an offering for Islamic mental health using preventive, curative, constructive, and rehabilitative. Aspects of faith, devotion, charity, moral and tasawuf are likely to form clinical Islam. ${ }^{21}$ Faith, devotion, charity, moral and tasawuf are tazkiyya al-nafs (purifying soul) that is dirtied by the world disgrace.

Islamic mental health through preventive, curative, constructive, and rehabilitative can grow good personality and mental health. ${ }^{22}$ Offering applicative faith makes human beings realize that they are observed by Allah all of the time. ${ }^{23}$ Psychologically, a Moslem is able to control his needs to avoid doing bad things. In addition, devotion not only has posi-

\footnotetext{
${ }^{18}$ Harun Nasution, Islam Rasional, Bandung: Mizan, 1997, 23.

${ }_{19}$ Nurcholish Madjid, Pintu-Pintu Menuju Tuhan,, Jakarta: Paramadina, 1992, 102.

${ }^{20}$ Muhammad Utsman Najati, Al-Qur'an wa 'Ilm al-Nafs, al-Kaherah: Dār al-Shuruq, 2001, 235.

${ }^{21}$ Jalaluddin Rahmat, Renungan-Renungan Sufistik, Bandung: Mizan, 1992, 37.

${ }^{22}$ Yahya Jaya, Spiritualisasi Islam dalam Menumbuhkembangkan Kepribadian dan Kesehatan Mental, Jakarta: Ruhama, 1992, 15.

23 Javad Nurbakh,"Tasawuf dan Psikoanalisa: Konsep Iradah dan Transferensi dalam Psikologi Sufi", dalam Jurnal Ilmu dan Kebudayaan; Ulumul Qur'an, No. 8 (1991), 13.
} 
tive function for 'ábid (Allah servant) to worship with all some one's heart and soul, ${ }^{24}$ but also motivates human beings to behave better. Moral and tasawuf are the manifestation of faith that is able to be Islamic personal model that is obedient to Allah. ${ }^{25}$ Values in tasawuf moral play a therapeutic role to obtain perfect mental health. Moral and tasawuf are also able to adjust the relationship among Allah, human beings and environment.

Human beings, in terms of the psychology aspect are called a creature which is full of questions and difficult to understand. Psychology is hard to study because of the complexity of human's behavior. The Quran states that human is, i.e.:

Created in the best of mould..$^{26}$

Given things good and pure and confessed special favors, above a great part of Our creation. ${ }^{27}$

Given its enlightenment as to its wrong and its right. ${ }^{28}$

Then, in the process to get perfection, human stands as a subject that is conscious and free to choose; good or bad ways, taqwa or fujr; either a save way or destroying way. In other ayahs of the Quran, it is stated that:

Man is given to hasty (deeds). ${ }^{29}$

Allah leaves straying those whom He pleased and guides whom $\mathrm{He}$ pleses. ${ }^{30}$

Truly man was created very impatient. ${ }^{31}$

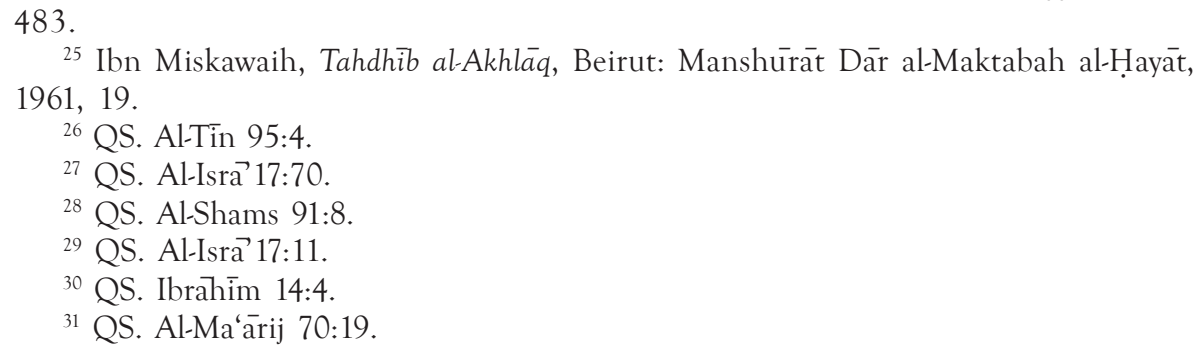
483.

${ }^{25}$ Ibn Miskawaih, Tahdhỉb al-Akhlāq, Beirut: Manshürāt Dār al-Maktabah al-Hayāt, 1961, 19.

${ }^{26}$ QS. Al-Tin 95:4.

${ }^{27}$ QS. Al-Isra 17:70.

${ }^{28}$ QS. Al-Shams 91:8.

${ }^{29}$ QS. Al-Isra 17:11.

30 QS. Ibrahìm 14:4.

${ }^{31}$ QS. Al-Ma‘̄arij 70:19.

${ }^{24}$ Lois Ma'luf, Munjid fi al-Lughah wal A'lam, Beirut: Maktabah al-Sharkiyyah, 1986, 
But man is, in most things, contentious. ${ }^{32}$

But actually the case is that human is very weak. ${ }^{33}$

Islamic mental health is emotional and psychological power studying human as a subject who follows a religion; from ritual dimension, credoism, and norms that are applied by social community related to mental health. In other words, it tries to find out psychological aspects that are integrated with values. So, the study is highly related to the formation of moral, positive or negative. Standardization of having moral or not emerges various opinions. One of them is an opinion stating that a good moral can be measured by the appearance of high solidarity, forgiveness, awareness not to bother someone's happiness, and keeping a good relationship with his God. ${ }^{34}$ Moral will reflect human as a physical and psychological creature because human reflects his moral through good behavior, then he is able to prove himself created in the best appearance (ahsan altaqwim). Human will lose his identity without good moral. That's why he will live without his own identity or human without moral (asfala sâfilin). ${ }^{35}$

Psychological aspects of human beings consisting of heart, spirit, desire and mind need care and growth so that it is always in salam, or Islam. This atmosphere must be maintained so that human beings can give useful contribution. The Quran touches feelings, i.e. in ayahs that reads:

Truly it is not their eyes that are blind, but their hearts which are in their breasts. ${ }^{36}$

But man inclined to the earth, and followed his vain desire. ${ }^{37}$

32 QS. Al-Kahf 18:54.

${ }_{33}$ QS. Âlu 'Imrān 3:28.

${ }^{34}$ Imam Al-Ghazali, Tahdhỉb al-Akhlāq wa Mu'allajat Amrad al-Qulü, transl.Muhammad al-Baqir, Bandung: Mizan, 1994, 29-31.

${ }^{35}$ Djohan Effendi, "Tasawuf Al-Qur'an Tentang Perkembangan Jiwa Manusia”, Jurnal Ilmu dan Kebudayaan Ulumul Qur'an, No.8 (1991), 5.

${ }^{36}$ Qs. Al-Hajj 22:46.

${ }^{37}$ QS. Al-A'rä 7:176. 
That He may make suggestions thrown in by Satan, but a trial for those in whose heart is a disease and who are hardened of hearth. ${ }^{38}$ In their hearts is a disease; and Allah has increased; and grievous is the penalty they incur, because they are false to themselves. ${ }^{39}$ By no means! But on their hearts is the stain of the (ill) they do!40 Allah hath set a seal on their hearts and on their hearings and on their eyes is a veil; great is the penalty they incur. ${ }^{41}$

To such (deceit) let the hearts of those incline, who have no faith in the Hereafter: let them delight in it, and let them earn from it what they may. ${ }^{42}$

The Day whereon neither wealth nor sons will avail but only he (will prosper) that brings to Allah a sound hearth. ${ }^{43}$

And know that Allah cometh in between man and his hearth. ${ }^{44}$ And if anyone believes in Allah, Allah guides his heart (aright). ${ }^{45}$

Feeling with various deviations deduces that sincere feeling determining the nature of human is the heart that is able to understand himself and his environment. In order to have a sincere feeling and to gain what is needed, Islamic laws are required. The stage, spiritually, can be obtained by worshipping God regularly. A worshipping activity done sincerely and continuously gives a better mental condition. ${ }^{46}$ Heart which is free of jealousy, arrogance, complaining, and gossiping will bring open doors to a right path and play significant roles to guide moral to better ways.

${ }^{8}$ QS. Hajj 22:53.

${ }^{39}$ QS. Al-Baqarah 2:10.

${ }^{40}$ QS. Al-Mutaffifin 83:14.

${ }^{41}$ QS. Al-Baqarah 2:7.

${ }^{42}$ QS. Al-An'am 6:113.

43 QS. Al-Shu'arả 26:88,89.

${ }^{44}$ QS. Al-Anfal 8:24.

45 QS. Al-Taghabun 64:11. 61.

${ }^{46}$ Sayyid Hawwa, Tarbiyah al-Rụhāniyah, transl. Kahirul Rafie, Bandung: Mizan, 1998, 
Islam justifies the essentials of spirit of human beings, but the nature of spirit is not human's business. The Quran states that:

They ask you thee concerning Spirit (of inspiration). Say: 'Spirit (cometh) by command of Lord: of knowledge it is only a little that is communicated to you, (O men!)." 47

Opinions about spirit essence in individuals, verily, belong to Allah, and human's mind can reach the nature of the spirit itself. In the early day of human's creature, spirit was introduced to Allah, He explains in the Quran:

When the Lord drew forth from the children of Adam from their loins, their descendants, and made them testify concerning themselves, (saying): "Am I not your Lord (who cherishes and sustains you)?” They said: "Yea! We do testify!" 48

But human's spirit is influenced by a number of factors. Household influences spirit very much to make it good or bad. Attitude that is out of control or without the faith, triggers crime, arrogance and violations of God's law. These two factors motivate spirit to act speculatively and carry out social deviation. In order to keep spirit in Lațifa rühāniyya rabbaniyya (in the right path), spirit needs equality between knowledge and charity. It is relevant to the consequence of the spirit that has known God when it was firstly created and when it witnessed that Allah is God of the universe.

Desire in human's life can be a positive energy, but it sometimes motivates individual to do bad things. The word 'desire' in the Quran has several categories. They are nafs al-ammārah (destructive desire), nafs allawwämah (eschew Evil) and nafs al-mutma'innah (the righteous soul). ${ }^{49}$ Sometimes nafs al-ammārah is trapped in bi al-sü' (bad action) bent down

\footnotetext{
${ }^{47}$ QS. Al-Isrā' 17:85.

${ }^{48}$ QS. Al-A'rāf 7:172.
} 
to bad desire and Satan. Allah says:

"Nor do I absolve my own self (of blame): the human (soul) is certainly prone to evil, unless my Lord does bestow His Mercy, but surely my Lord is Oft-Forgiving, Most Merciful." ${ }^{0}$

Nafs allawwämah (eschew Evil) tends to do bad things but he soon realizes his mistakes and returns back to repent and forswear to Allah. Desire teases the owner when the owner is negligent to obey his God Allah saying:

And I do call to witness the self reproaching spirit; (eschew Evil). ${ }^{51}$

When desire is bent down to Allah, obey Him, feel anxious and worried because he does not obey Allah, the desire is called nafs al-mutma'innah (peaceful soul). ${ }^{52}$ Allah states in the Quran:

(To the righteous soul will be said) "O (thou) soul, in (complete) rest and satisfaction. ${ }^{53}$

Mind plays important roles in human's life and every individual is responsible for anything he does with his God. Mind, like spirit and desire also has a tendency to do good or bad things. However, mind contains taklifi, or rational mind to do something based on God's omnipotence.

Four human's psychological dimensions, namely heart, spirit, desire and mind, have a potential to guide and develop towards akhlaq al-karimah suitable with the nature of mankind that is pure, plain and clean obtained when he was born. Prophet Muhammad says:

\footnotetext{
${ }^{49}$ Budhi Munawwar-Rachman, Kontekstualisasi Doktrin Islam dalam Sejarah, Jakarta: Paramadina, 1995, 21.

${ }^{50}$ QS.Yūsuf 12:53.

${ }^{51}$ QS. Al-Qiyāmah 75:2.

52 Sayyid Hawwa, Tarbiyah al-Rūhāniyah..., 46.

${ }^{53}$ QS. Al-Fajr 89: 27 and 28.
} 
Each child was purely born. His parents make him become a Jewish, Christian or Zoroastrian". 54

Allah says:

So set thou thy face steadily and truly to the Faith: (establish) Allah's handiwork according to the pattern on which He has made mankind: no change (let there be) in the work (wrought) by Allah: that is the standard Religion: but most among mankind understand not. ${ }^{55}$

Islam considers mankind a unique component that needs guidance and development in order that he knows himself and approaches his Lord. By then, an individual will reach the high spiritual level, gain perfect and pure soul. The effort to get the high spiritual level, according to Sufism, is called tazkiyya al-nafs, a process of psychological development toward al-falāh (winning), al-najāh (successful), and mutma'innah (righteous). Success and happiness - alsa ${ }^{\prime}$ adah) are actually a collection of righteous soul in a person. ${ }^{56}$ The righteous soul (mutma'innah) can be reached by bearing in mind and worshipping Allah. ${ }^{57}$ The righteous soul or happiness is not well manifested without omitting disturbance that may handicap the process of tazkiyya al-nafs. The disturbance is usually derived from bad attitude, sin, guilt, and revenge. ${ }^{58}$ Psychologically, a person who is sinful and who violates the God' law is worried and anxious as long as he is still sinful..$^{59}$ Therefore, Islamic mental health needs to obtain comprehensively. It can help psychologists to solve psychological problems, especially those related to light and heavy depression, psychopathology, psychoneurosis, stress and so on.

\footnotetext{
${ }^{54}$ Muslim Ibn Hajjaj al-Qusyairy, Sahīh Muslim bi Sharh Imam Muhy al-Din al-Nawāwi alMusamma al-Minhaj, Beirut: Dār al-Ma'rifah, 1914, 242.

${ }^{55}$ QS. Al-Rūm 30:30.

${ }^{56}$ Zakiah Darajat, Kebahagiaan, Jakarta: Ruhama, 1988, 13.

${ }^{57}$ QS. Al-Ra'd 13:29.

${ }^{58}$ Zakiah Darajat, Puasa Meningkatkan Kesehatan Mental, Jakarta: Ruhama, 1989, 18.

59 Yahya Jaya, Peranan Taubat dan Maaf dalam Kesehatan Mental, Jakarta: Ruhama, 1992, 58.
} 
Islamic mental health is very important to develop sciences in general and psychology in particular. Islamic mental health proposes a new method by using the Quran and Hadith of Prophet Muhammad's approach stressing aspects of belief, worship, devotion, moral and tasawuf. It also proposes theoretical, practical, methodological formula and its implementation in real life.

\section{The model of Islamic psychotherapy}

A model of Islamic psychotherapy explained in this part is the treatment of the mental disorder in Islamic Boarding School of Suryalaya, Tasik Malaya, West Java. Pondok Remaja Inabah Pondok Pesantren Suryalaya (Suryalaya Boarding school) was established because there were some requests from local community in Suryalaya to help people in the community suffering from their mental disorder. Historically, Pondok Remaja Inabah was established in 1973. Then, it was officially declared in 1980 as Pondok Remaja Inabah I based on the idea of KH. Shahibul Wafa Tajul Arifin (called Abah Anom), a respected religious teacher in Pondok Pesantren Suryalaya. The establishment of Pondok Remaja Inabah aims to protect and guide the teenagers who misuse illegal drugs. Other mission is to recover their mental health and spirituality to the right path based on Allah's blessing. The methodology of psychotherapy in Suryalaya is practiced by using Ilahiyah's approach based on the application and functional principles of Islamic Sufism of Qodiriyyah-Naqsyabandiyyah. ${ }^{60}$ The teenagers addicted to illegal drugs substances can interact with other common students. In this boarding school, this treatment is intended to develop character building and adaptation based on the equality by per-

${ }^{60}$ KP. Anang Syah, Inabah; Metode Penyadaran Korban Penyalahgunaan NAPZA (Narkotika, Psikoterapika, dan Zat Adiktif lainnya), di Inabah I Pondok Pesantren Suryalaya, Tasikmalaya: PP. Suryalaya, 2000, 17. An interview with KP. Zainal Abidin Anwar on 02 Mei 2005, at 16.30 WIB in his house. 
forming religious service to Allah and making good relationship with human beings. With this principle, a patient feels worthy since he has equal rights in Allah's view. Allah only puts the one who has the highest piety on the highest level of His side. Psychotherapists using this approach try to recover the religious consciousness of the patient. ${ }^{61}$

The name of Pondok Remaja Inabah has a close relationship with its aim as the process of psychotherapy practiced. An adult is hoped to recover his consciousness into the right path based on Islamic values. Inabah means return to Allah's path. Rituals performed by the patient are rituals making him close to Allah, increasing his piety, and getting His love (mahabbah). A person suffering from mental disorder can be cured if he follows inābah, i.e. returning to Allah's path.

Inabah, basically, is derived from al-Quran. There are eight words having similar meaning with inabah. It can be seen from the term of anaba in surah al-Ra'd 13:27, Luqman 31:15, Shad 38:24. The term of anabu can be read in surah al-Zumar 39:17. The word of unibu can be seen in surah Hud 11:88 and surah al-Syura 42:10. The term of anibu can be read in surah al-Zumar 39:45. The word of munibu can be seen in surah Hud 11:75, Saba' 34:9, Qhaf 50:8 and 23. The word of muniban can be read in surah al-Zumar 39:8. Those words mean returning to Allah with the highest piety. While in Islamic Sufism, inäbah is a name of station or stage (maqūm) which should be followed by sălik after he follows maqām murăqabah. The followers of Islamic Sufism say that one of the implementations of murāqabah is inābah. This means that one returns to follow the Allah's teaching and does not perform immoral acts because he is shy "to be observed by God". ${ }^{6}$

${ }^{61}$ Harun Nasution, Tarekat Qodiriyyah-Naqsyabandiyyah: Sejarah, Asal Usul dan Perkembangannya, Tasikmalaya: IAILM, 1992, 392.

${ }^{62}$ Juhaya S. Praja, Spiritualisasi Islam..., 59 and an interview with KP. Selamat Rahmat, SH on 02 Mei 2005, after Isya' prayer in Yayasan Serba Bhakti Pondok Pesantren Suryalaya. 
The term of inäbah is developed by Abah Anom as conceptual idea and methodology of psychotherapy to cure the mental disorder of human beings. Some years ago, patients in Pondok Pesantren Suryalaya; in which the process of psychotherapy was done by Abah Anom. However, the number of patients has increased in each day. As a result, Suryalaya Boarding School has opened new branches such as some Inābah's Islamic boarding schools as the branches of Pondok Remaja Inabah Islamic Boarding school Suryalaya. Recently, there are 39 branches of Pondok Inābah, in which 35 of them are located in some provinces and the rest is in foreign countries like in Malaysia and Singapore.

\section{Procedure and method of psychotherapy}

In Pondok Inabah, Abah Anom wisely makes a clear procedure and method of psychotherapy. With systematic procedure, Abah Anom as therapist has practiced a good method so that he can treat his patient well. Abah Anom formulates some stages and curricula which must be followed by his patients:

\section{Identification stage}

In this stage, the patient's parents or relatives provide clear, true and open information related to the condition of the patient. It is intended to know the identity of the patient and how far the patient has been addicted to the illegal drugs.

1. The stage of taking a bath as symbol of asking for Allah's forgiveness. The stage is intended to reduce the patient's addiction of illegal drugs. Besides, the patient is poured with water of Javanese acid mixed with brown sugar or the water of green coconut. This procedure will reduce radiation, addiction, and detoxify the patient from bad substances such as drugs. 
2. The stage of receiving talqin dhikr or chant's instruction. In Islamic Sufism of Qodariyya-Naqsyabandiyya, talqin dhikr is an important part. During this treatment, the patient is obliged to know the knowledge of performing good dhikr. Kinds of the dhikr taught are both silent dhikr and loud dhikr.

3. The stage of following the treatment and character building. In this stage, a patient should perform religious ritual and good deeds continuously stated curriculum made by Abah Anom as follows:

- At 02.00 in the morning, a patient shall wake up and take a bath. Before taking a bath and entering bath room, he shall say a prayer reading as follows:

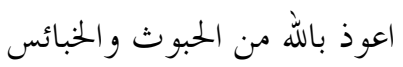

I need Allah's help from satan's temptation.

- When a patient is already in bath room and started to take a bath, he shall say a prayer reading as follows:

$$
\text { ربي انزلي متزالا مبار كا وانت خير المتزلين }
$$

O, Allah give me Your blessing since You are the best giver (QS. alMu'minūn 23:29).

- After taking a bath and going out from bath room, a patient with builder's guidance says a prayer reading as follows :

$$
\text { الحمدللة الذي عذاب عين وعفي اشهد ان لااله الا الله واشهد ان محمد رسوالله }
$$

God be praised for curing my disorder and giving my health; there is no God other than Allah and the Prophet Muhammad is His Messenger.

- After saying above prayer and arriving home, a patient is obliged to perform prayer of gratitude of ablution to God or shalat Shukr alWudù ' with two units or 2 raka'at and one greeting or 1 salam, with 
intention or niyat reading as follows:

$$
\text { اصلي سنة شكر الوضؤ ركتين للّ تعالئ الله اكبر }
$$

I intend to perform a prayer of Him, the Almighty God.

- Then, a patient shall go to the mosque and do a prayer of attending the mosque or Tahiyyat al-Masjid consisting of two units or 2 raka'at, and one greeting or saläm. Its intention is reading as follows:

$$
\text { اصلي سنة تحية المسجد ركعتين لله تعالئ الله اكبر }
$$

I intend to do a prayer of attending the mosque consisting of two units for Allah, the Almighty God.

- After doing the prayer, a patient shall perform a prayer of asking the God for forgiveness consisting of two units (raka'at) and one greeting. Its intention is reading as follows:

$$
\text { اصلي سنة التوبة ركعتين لله تعالئ الله اكبر }
$$

I intend to do prayer of asking the God for forgiveness consisting of two units for Allah, the Almighty God.

- After that, a patient shall do the prayer of evening or Tahajjud consisting of 12 unit and six greetings. Its intention is reading as follows:

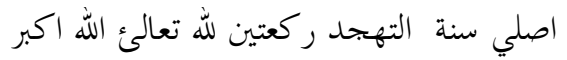

I intend to do prayer of evening consisting two units for Allah, the Almighty God.

- Next, a patient is obliged to perform prayer of praising God or Tasbih consisting of four units and two greetings. Its intention is reading as follows:

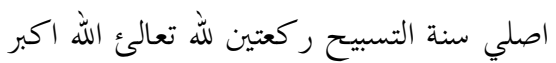


I intend to do prayer of asking the God for forgiveness consisting of two units because of Allah, the almighty of God. Since this prayer is prayer of praising God, a patient should praise God as much as possible by saying:

$$
\text { سبحان الله والحمدلله ولااله الا الله والله اكبر ولاحولا قوة الا بالله العلي العظيم }
$$

All praise be to Allah, the almighty of God. There is no God but Allah, the almighty of God. There is no power except from Allah, the Almighty God.

- Techniques of praising God or saying tasbih as follows:

$>$ After saying al-Fätihah and other verses, a patient stands by praising God or saying tasbih 15 times.

$>$ During performing bow in prayer or ruku', a patient says tasbih 10 times.

> During proper standing or I'tidal, a patient says tasbih 10 times.

$>$ During bow from kneeling position or sujud a patient says tasbih 10 times.

$>$ During sitting in the middle of prayer, a patient says tasbih 10 times.

$>$ During the second bow from kneeling position, a patient says tasbih 10 times.

$>$ During getting up from the second bow from kneeling position, a patient says tasbih 10 times.

- After that prayer, a patient shall do the evening prayer or Witr, 11 units, and 5 greetings. Each prayer consists of two units and the sixth prayer consists of only one unit. This prayer can be done in three units with two greetings. The intention of this prayer is reading as follows:

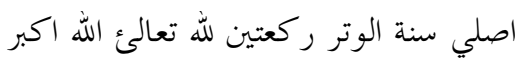


IJIMS, Indonesian Journal of Islam and Muslim Societies, Volume 4, Number 2, December 2014: 257-289

I intend to do the prayer of evening or Witr consisting of two units for Allah, the Almighty God.

- After doing that prayer, a patient is obliged to praise God as much as possible either silently or loudly until the time to do the dawn prayer comes.

- When it is the time for doing the dawn prayer, a patient is obliged to do the optional prayer before the dawn prayer consisting of two units and one greeting. Its intention is reading as follows:

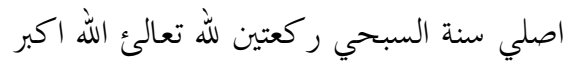

I intend to do optional prayer before the dawn prayer consisting of two units for Allah, the Almighty God.

- After the prayer, a patient shall do an optional prayer for avoiding disaster Li daf' al-balā' consisting of two units and one greeting. Its intention is reading as follows:

$$
\text { اصلي سنة شكر لدفع البلاء ركعتين لله تعالئ الله اكبر }
$$

I intend to do prayer of avoiding disaster consisting of two units for Allah, the almighty of God.

- Next, a patient shall do dawn prayer consisting of two units and one greeting. Then a patient shall perform religious ritual loudly by saying:

$$
\text { لاله الله }
$$

165 times or more, tawassul, and read to oneself (ALLAHU).

- At 6.00 in the morning, a patient is obliged to do the prayer of Ishrāq consisting of two units and one greeting. Its intention is reading as follows:

$$
\text { اصلي سنة الأسشرق ركعتين لله تعالئ الله اكبر }
$$


I intend to do the prayer of Ishrāq consisting of two units for Allah, the Almighty God.

- Then, he does the prayer of Isti'adhah consisting of two units and one greeting. Its intention is reading as follows:

$$
\text { اصلي سنة الأستعاذة ركعتين لله تعالئ الله اكبر }
$$

I intend to do the prayer of Isti'adhah consisting of two units for Allah, the Almighty God.

- Then, he performs the prayer of Istikhārah consisting of two units and one greeting. Its intention is reading as follows:

$$
\text { اصلي سنة الأستخارة ركعتين لله تعالئ الله اكبر }
$$

I intend to do the prayer of Istikhärah consisting of two units for Allah, the Almighty God.

- After that, a patient continues his saying the prayer of Istikharah (based on his intention).

- At 09.00 in the morning, a patient is obliged to do the prayer of Duhà consisting of eight units and four greetings. Its intention is reading as follows:

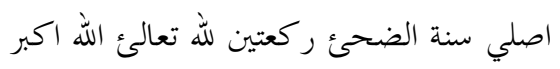

I intend to do the prayer of Duha consisting of two units for Allah, the almighty of God.

- Next, he shall do the prayer of Kifarat al-bawl consisting of two units and one greeting. Its intention is reading as follows:

$$
\text { اصلي سنة لكفارة البول ركتين للّ تعالئ الله اكبر }
$$

I intend to do the prayer of Kifarat albawl, two units for Allah, the Almighty God.

- At 12.00 at noon, a patient shall do the optional prayer before the prayer of Zuhr consisting of two units and one greeting. Its intention 
is reading as follows:

$$
\text { اصلي سنة الظهر قبلية ركعتين لله تعالئ الله اكبر }
$$

I intend to do the optional prayer before the prayer of Zuhr consisting of two units for Allah, the Almighty God.

- Then, a patient shall do the prayer of Z\}uhr consisting of 4 units and one greeting. Its intention is reading as follows:

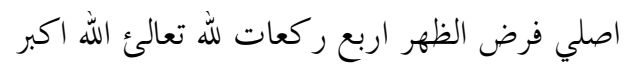

I intend to do the prayer of Zuhr consisting of four units for Allah, the Almighty God.

- After that, a patient says:

165 times, then tawassul, by reading to oneself ALLAHU. Then, he shall do the optional prayer after the prayer of Zuhr. The intention is reading as follows:

$$
\text { اصلي سنة الظهر بعدية ركعتين لله تعالئ الله اكبر }
$$

I intend to do prayer of the optional prayer after the prayer of Zuhr consisting of two units for Allah, the Almighty God.

- At 15.00 in the afternoon, when it is a time to do the prayer of 'Asr, a patient is obliged to do the optional prayer before the prayer of 'Asr consisting of two units and one greeting. The intention is reading as follows:

$$
\text { اصلي سنة العسرقبلية ركتين لله تعالئ الله اكبر }
$$

I intend to do the optional prayer before the prayer of 'Asr consisting of two units for Allah, the Almighty God.

- After doing the prayer, a patient shall do the prayer of 'Asr consisting of 4 units 1 and greeting. Its intention is reading as follows: 


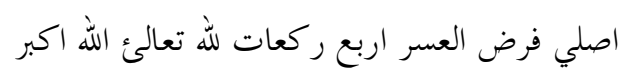

I intend to do the prayer of 'Asr consisting of four units for Allah, the almighty of God.

- Then, a patient should say:

$$
\text { لا اله الا الله }
$$

165 times or more, after that he shall do tawassul and read to himself ALLAHU.

- At 16.00 in the afternoon when it is time to do the prayer of Maghrib, a patient shall do the optional prayer before the prayer of Maghrib consisting of two units and one greeting. The intention is reading as follows:

$$
\text { اصلي سنة المغريب قبلية ركعتين لله تعالئ الله اكبر }
$$

I intend to do the optional prayer before the prayer of Maghrib consisting of two units for Allah, the almighty of God.

- Then, a patient shall do the prayer of Maghrib consisting of 3 units and one greeting. Its intention is reading as follows:

$$
\text { اصلي فرض المغريب ثلاذة ركعات للّ تعالئ الله اكبر }
$$

I intend to do the prayer of Maghrib consisting of three units for Allah, the almighty of God.

After that, he shall say:

$$
\text { لاله الا الله }
$$

165 times, tawassul and read to himself ALLAHU.

- After that, a patient shall do the optional prayer of Maghrib consisting of two units and one greeting. Its intention is reading as follows: 


$$
\text { اصلي سنة مغريب بعدية ركعتين لله تعالئ الله اكبر }
$$

I intend to do the optional prayer after the prayer of Maghrib consisting of two units for Allah, the almighty of God.

- Then, a patient shall do the optional prayer of Awwābin consisting of 6 units and 3 greetings. Its intention is reading as follows:

$$
\text { اصلي سنة الأو ابين ركعتين للّ تعالئ الله اكبر }
$$

I intend to do the optional prayer of Awwäbin consisting of two units for Allah, the Almighty God.

- Next, he shall do the prayer of Tawbah consisting of two units one greeting. Its intention is reading as follows:

$$
\text { اصلي سنة توبة ركعتين لله تعالئ الله اكبر }
$$

I intend to do the optional prayer of Tawbah consisting of two units for Allah, the Almighty God.

- Then, he shall do the optional prayer of Birr al-Walidayn consisting of two units and one greeting. Its intention is reading as follows:

$$
\text { اصلي سنة بر الوالدين ركعتين للّ تعالئ الله اكبر }
$$

I intend to do the optional prayer of Birr al-Walidayn consisting of two units for Allah, the Almighty God.

- After that, he shall do the optional prayer of li hifz al-imān consisting of two units and one greeting. Its intention is reading as follows:

$$
\text { اصلي سنة لحفظ الأيمان ركعتين لله تعالئ الله اكبر }
$$

I intend to do the optional prayer of li hifz al-imān consisting of two units for Allah, the Almighty God.

- After li hifz al-imān, he shall do the prayer of li shukr al-ni'mah consisting of two units and one greeting. Its intention is reading as follows: 


$$
\text { اصلي سنة لشكر النعمة ركعتين للّ تعالئ الله اكبر }
$$

I intend to do the optional prayer of li shukr al-ni'mah consisting of two units for Allah, the Almighty God.

- At 19.00 in the afternoon when it is time to do the prayer of 'Ishà', he shall do the optional prayer before the prayer of 'Isha' consisting of two units and one greeting. Its intention is reading as follows:

$$
\text { اصلي سنة لشكر النعمة ركتين للّ تعالئ الله اكبر }
$$

I intend to do the optional prayer before the prayer of 'Ishä'consisting of two units for Allah, the Almighty God.

- Next, a patient shall do the prayer of 'Ishä' consisting of four units one greeting. Its intention is reading as follows:

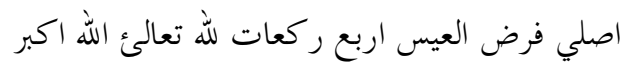

I intend to do the prayer of 'Isha' consisting of four units for Allah, the Almighty God.

- After that, he shall do the optional prayer after the prayer of 'Isha' consisting of two units and one greeting. Its intention is reading as follows:

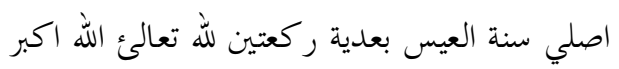

I intend to do the optional prayer after the prayer of 'Isha' consisting of two units for Allah, the Almighty God.

- Then, a patient shall say:

There is no God, but Allah

165 times or more, after that he shall do tawassul and read to himself ALLAHU. 
- Before going to bed, at 21.30 p.m. he shall take ablution and perform the optional prayer of shukr al-wudū' consisting of two units and one greeting. The intention is reading as follows:

$$
\text { اصلي سنة شكر الوضؤ ركتين لله تعالئ الله اكبر }
$$

I intend to do the optional prayer of shukr al-wudì ' consisting of two units for Allah, the Almighty God.

- After that, he shall do the optional prayer of mutlaq consisting of two units and one greeting. Its intention is reading as follows:

$$
\text { اصلي سنة مطلاق ركتين لله تعالئ الله اكبر }
$$

I intend to do the optional prayer of mutlaq consisting of two units for Allah, the Almighty God.

- Next, he shall do the optional prayer of istikhārah consisting of two units and one greeting. Its intention is reading as follows:

$$
\text { اصلي سنة الأستخارة ركتين لله تعالئ الله اكبر }
$$

I intend to do the optional prayer of Istikharah consisting of two units for Allah, the Almighty God.

- Then, he shall do the optional prayer of hăjat consisting of two units and one greeting. Its intention is reading as follows:

$$
\text { اصلي سنة الحاجة ركتين لله تعالئ الله اكبر }
$$

I intend to do the optional prayer of hajat consisting of two units for Allah, the Almighty God.

- Before going to bed, he shall say a prayer. It is reading as follows:

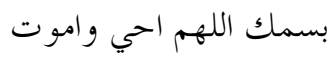

In the name of Allah, I give my life and my death to Him. While he says that prayer, he turns his head right, his hand is put under his 
right cheek, then he reads one word of Asmāa al-Husnā until he falls asleep.

- When he gets up, he shall say:

$$
\text { الحمدللة الذي احينا بعدما اماتنا واليه النشوار }
$$

All praises be to Allah who gives me a life after we slept and we will return to Him.

- In daily life, as being exercise for him, a patient shall say a prayer before eating and after eating, as well as behave properly when visiting someone. The prayer before eating is reading as follows:

$$
\text { اللهم بارك لنا فيما رزقتنا وقينا عذاب النار }
$$

$\mathrm{O}$, Allah, give me your blessing and your fortune and keep me away from the hell.

The prayer after eating is reading as follows:

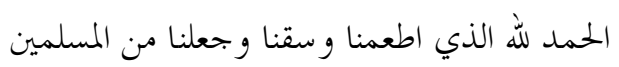

All praises be to Allah who has given us food and drink and has made us as Muslim.

A patient shall say greeting that is reading as follows when he meets other Muslims:

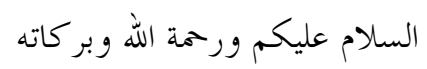

May Allah give you the safety and bless.

In addition, a patient shall answer other Muslim's greeting that is reading as follows:

$$
\text { وعليكم السلام ورحمة الله وبر كاته }
$$

May Allah give you the safety and bless too. 
IJIMS, Indonesian Journal of Islam and Muslim Societies, Volume 4, Number 2, December 2014: 257-289

Those above explanation is the curriculum implemented in Pondok Remaja Inābah led by Abah Anom. During their treatment, all patients shall follow those programs.

The implementation of Islamic psychotherapy through the method of Qadariyyah-Naqsyabandiyyah at Suryalaya Boarding School can be seen in the following table:

The number of patients during their treatment in 10 inabah from 1981 to 1989 is seen as follows:

\begin{tabular}{|c|c|c|c|c|c|c|c|}
\hline \multirow{2}{*}{$\begin{array}{l}\text { Num- } \\
\text { ber } \\
\text { Inab }\end{array}$} & \multirow[b]{2}{*}{ Gender } & \multirow[b]{2}{*}{ Year } & \multirow{2}{*}{$\begin{array}{c}\text { The } \\
\text { number } \\
\text { of } \\
\text { patient }\end{array}$} & \multirow{2}{*}{$\begin{array}{c}\text { Patients } \\
\text { who are still } \\
\text { treated }\end{array}$} & \multicolumn{2}{|c|}{ Results } & \multirow[b]{2}{*}{ Die } \\
\hline & & & & & Recovered & Unresolved & \\
\hline I & M & 1981 & 1,496 & 46 & 1405 & 46 & 2 \\
\hline II & $F$ & 1981 & 560 & 19 & 528 & 22 & 1 \\
\hline III & $\mathrm{M}$ & 1981 & 524 & 4 & 503 & 21 & - \\
\hline VIa & $\mathrm{M}$ & 1983 & 408 & 18 & 367 & 19 & 2 \\
\hline $\mathrm{VIb}$ & $\mathrm{F}$ & 1983 & 189 & 8 & 178 & 8 & - \\
\hline VII & $M$ & 1985 & 944 & 23 & 912 & 9 & 1 \\
\hline XI & $M$ & 1985 & 689 & 40 & 617 & 32 & 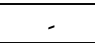 \\
\hline $\mathrm{XV}$ & $\mathrm{M}$ & 1985 & 749 & 32 & 688 & 29 & 1 \\
\hline XVII & $\mathrm{F}$ & 1986 & 199 & 9 & 189 & 1 & - \\
\hline XXI & $\mathrm{F}$ & 1986 & 67 & 12 & 55 & - & - \\
\hline Total & & $\begin{array}{l}1981- \\
1989\end{array}$ & 5.825 & 211 & 5,442 & 187 & 7 \\
\hline Ratio & $\%$ & & 100 & 3.6223 & 93.424 & 3.2103 & 0.1201 \\
\hline
\end{tabular}

Remarks:

$\mathrm{M}=$ Male

$\mathrm{F}=$ Female

Sources: Dr. Eko Kastama P.Exploration Study to Concerning Inābah Method, in Effort Addictive Patient and drug to Educative Process according at Islamic boarding in Suryalaya

The number of patient who were treated from 1981 to 1989 were 5,825 and 212 of them $(3,6 \%)$ are still being treated. The number of recovered patient who left the boarding school is 5,426 (93.4\%). However, 187 patients were not cured yet or unresolved (3.2\%), and 7 patient 
died $(0,1 \%)$. This tabulation shows that there is a high possibility for patients to be recovered since there are 212 patients who are still being treated.

\section{Conclusion}

Psychotherapy is an effort has been done by therapists in order to cure the mental disorder by using the methodology of psychotherapy. Psychotherapy is part of psychology studying the development of psychological problem of human beings. Based on the development of knowledge, psychotherapy appears with many methods, theories, and backgrounds. Sigmund Freud named his theory as Psychoanalytic, Abraham Maslow proposed his theory as Humanistic, while John B. Watson called his theory as B. Watson called his theory Behavioral Psychotherapy.

Islamic psychotherapy is oriented to the concept and the method derived from the Quran and Sunnah. Both of them are divine revelation containing psychological knowledge used as methodology of Islamic Psychotherapy. In fact, the Quran and Hadith provide a lot of information about science, as some verses (surah) explain mind, desire, soul, and heart. Both the Quran and hadith explain motivation, emotion, desire, mind, potency, and so on. They have methodology that can be implemented in Muslim's life. Since it is based on the Quran and hadith, this methodology can be called as methodology of Islamic Psychotherapy.

By looking at a model of Islamic Psychotherapy practiced in Islamic Boarding school Suryalaya, it justifies that there are some methodologies of Psychotherapy in Islam. A model of Islamic Psychotherapy in Islamic Boarding school Suryalaya is simple but it succeeds in recovering thousands of patients suffering from mental disorder. Islam does not only belong to Qodariyyah-Naqsyabandiyyah. This Islamic Sufism is only a part of Islamic spiritual. Even, Islam, a holistic religion, can be used as meth- 
odology of Islamic Psychotherapy. Methodology of improving the faith, increasing good deeds, improving the piety, and joining Islamic Sufism are effective methods in Psychotherapy in curing the mental disorder.

\section{Bibliography}

Al-Ghazali, Imam. Tahdhīb al-Akhlāq wa Mu'allajat Amrad\} al-Qulūb. transl. Muhammad Al-Baqir. Bandung: Mizan, 1994.

Al-Musawi, Khalil. Kaifa Tabni Shahsiyatak transl. Ahmad Subandi. Jakarta: Lentera Basritama, 1995.

Al-Qahtani, Muhammad Sayyid et. Al. Memurnikan Lailahaillallah. Transl. Abu Fahmi. Jakarta: Gema Insani Press, 1993.

Al-Qusyairy, Muslim Ibn Hajjaj. Șahịh Muslim bi Sharh Imām Muhyi al-Dīn al-

Nawāwi al-Musamma al-Minhaj. Beirut: Dr al-Ma'rifah, 1914.

Bertens, K. Etika. Jakarta: Gramedia Pustaka Utama, 1997.

Darajat, Zakiah. Kebahagiaan. Jakarta: Ruhama, 1988.

Darajat, Zakiah. Puasa Meningkatkan Kesehatan Mental. Jakarta: Ruhama, 1989. Effendi, Djohan, "Tasawuf The Quran Tentang Perkembangan Jiwa Manusia" Jurnal Ilmu dan Kebudayaan Ulumul Qur'an, No.8 (1991).

Freud, Sigmund. Veber Psycho: Feung Vor Tesungea. Transl. K. Bertens. Jakarta: Gramedia, 1991.

Hawari, Dadang. Al-Quran: Ilmu Kedokteran Jiwa dan Kesehatan Jiwa. Yogyakarta: Dana Bhakti Primayasa, 1997.

Hawwa, Sayyid. Tarbiyah al-Rūhāniyyah. Transl. Kahirul Rafie), Bandung: Mizan, 1998.

Jaya, Yahya. Peranan Taubat dan Maaf dalam Kesehatan Mental. Jakarta: Ruhama,1992.

Jaya, Yahya. Spiritualisasi Islam dalam Menumbuhkembangkan Kepribadian dan Kesehatan Mental. Jakarta: Ruhama, 1992.

Lari, Sayyid Mujtaba Musavi. Psikologi Islam. Bandung: Mizan. 1993.

Ma'luf, Lois. Munjid fi al-Lughah wal A'lam. Beirut: Maktabah al-Sharkiyyah, 1986.

Madjid, Nurcholish. Pintu-pintu Menuju Tuhan. Jakarta: Paramadina. 1995.

Miskawaih, Ibn, Tahdhìb al- Akhlāq. Beirut: Manshūrāt Dār al-Maktabah alHayāt, 1961.

Najati, Muhammad Utsman. The Quran wa 'Ilm al-Nafs. Cairo: Dār al-Shuruq, 2001. 
Nasution, Harun. Islam Rasional. Bandung: Mizan, 1997.

Nasution, Harun. Tarekat Qodiriyyah-Naqsyabandiyyah: Sejarah, Asal Usul dan Perkembangannya. Tasikmalaya: IAILM, 1992.

Nurbakh, Javad, "Tasawuf dan Psikoanalisa: Konsep Iradah dan Transferensi dalam Psikologi Sufi", Jurnal Ilmu dan Kebudayaan Ulumul Qur'an, No. 8 (1991).

Proyek Pembinaan PTA. Pengantar Ilmu Tasawuf. Medan: IAIN Sumut, 1981. Rahardjo, Dawam, "Al-Nafs", Jurnal Ilmu dan Kebudayaan Ulumul Qur'an, No. 8 (1991).

Rachman, Budi Munawwar. Kontekstualisasi Doktrin Islam dalam Sejarah. Jakarta: Paramadina, 1995.

Rahmat, Jalaluddin. Renungan-Renungan Sufistik. Bandung: Mizan, 1992.

Suseno, Frans Magnis. Etika Dasar (Masalah-masalah Pokok Filsafat Moral). Yogyakarta: Kanisius, 1987.

Syah, KP. Anang. Inabah: Metode Penyadaran Korban Penyalahgunaan NAPZA (Narkotika, Psikoterapika, dan zat adiktif lainnya), di Inabah I Pondok Pesantren Suryalaya. Tasikmalaya: PP. Suryalaya, 2000.

Tasawuf dan Psikoanalisa: Konsep Iradah dan Transferensi dalam Psikologi Sufi" 